\title{
Reliability and validity of the Korean version of the Dental Fear Survey
}

\author{
Ah-Hyeon Kim', Youn-Soo Shim², So-Young Park, Hee-Won Kim", So-Youn $\mathrm{An}^{5}$ \\ 'Department of dentistry, Dental spa Clinic, Daejeon, ${ }^{2}$ Department of Dental Hygiene, College of Health Science, Sunmoon University, \\ Asan, ${ }^{3}$ Department of Dental Hygiene, College of Health Science, Vision University, Jeonju, ${ }^{4}$ DoJang Middle School, Gunpo, ${ }^{5}$ Department \\ of Pediatric dentistry, College of Dentistry, Wonkwang University, Daejeon, Korea
}

\begin{abstract}
Background: Many people experience varying levels of discomfort when confronted with the prospect of dental treatment. Dental treatment can be a traumatic experience, especially for children and adolescents with dental anxiety. In this age group, dental fear causes a significant problem in dental management and has been related to severe dental caries and dental pain. The Dental Fear Survey (DFS ) is the most widely used measure of dental fear. This study was undertaken to develop the Korean version of the DFS ( K-DFS ) and test its reliability and validity.

Methods: The K-DFS, which uses projective techniques to measure children's and adolescents' dental fear, was developed. The DFS was translated into Korean and participants were selected via convenience sampling. Reliability and validity were tested using data from a sample of 813 middle school students in Gyeonggi Province, selected from the Self questionnaire survey. The K-DFS was administered twice to 102 adolescents aged 12-15 years.

Results: The K-DFS had high internal consistency reliability (99.1\%) but low test-retest reliability.

Conclusions: The results indicate that the Korean versions of the DFS have good internal consistency reliabilities and test-retest validities. However, we need to further examine the test-retest reliability of the K-DFS and replicate the current study in different samples covering various age groups.
\end{abstract}

Key Words: Anxiety; Dental fear; Dental Fear Survey; Reliability; Validity.

\section{INTRODUCTION}

National oral health surveys are necessary to assess treatment needs, monitor oral health, plan effective community intervention programs and health policies, and evaluate progress toward health objectives. In Korea, an epidemiological survey performed by trained, calibrated examiners has been carried out by the Ministry of Health \& Welfare every three years from 2000 to 2012. Dental caries were assessed according to the World Health Organization diagnostic criteria. Decayed, missing, and filled surfaces and teeth (DMFS/DMFT) indexes were estimated. The DMFT index for 12-year-old children was
3.3 in 2000, 2.2 in 2006, and 1.8 in 2012. The prevalence of caries was higher among females than males and in rural than urban areas [1-3]. Despite the observed decreasing trend in caries experience indicators in Korea, the prevalence of caries is still considerably higher than that of other European countries as well as the targets set by WHO within the Health 21 policy [4] framework. Therefore, in Korea, there seems to be potential for caries reduction. Community-based oral disease prevention programs are urgently needed for the promotion of oral health. These differences remain when employment status and/or income are controlled for, indicating that financial disparities may not explain the higher caries rates, especially gender differences in caries prevalence. Dental
Copyright(c) 2015 Journal of Dental Anesthesia and Pain Medicine
Received: 2015. 6. 24. - Revised: 2015. 7. 5. - Accepted: 2015. 7. 6. Corresponding Author: So-Youn An, Department of Pediatric dentistry, College of Dentistry, Wonkwang University, 77 Dun- San Dong, Seo- Gu, Dae-Jeon Metrocity, 320-120, Korea Tel: +82-42-366-1135 Fax: +82-42-366-1115 E-mail: 9543sue@hanmail.net 
fear is known to contribute to dental avoidance [5]. One impact of not going to a dentist regularly is the increased likelihood of developing more serious dental problems, which may be manifested by the tendency to report that the most recent dental visit was due to pain or dental problem, compared with check-up [6]. However, evidence on the relationship between oral disease and dental fear is mixed; some researchers have found that high dental fear is associated with more caries [6,7] while others have not [8]. A higher number of missing teeth and fewer filled teeth are more consistently reported in fearful individuals [5-8], possibly due to a failure on their part to obtain dental care until the carious teeth cannot be restored and must be extracted. Lee et al. found that in Korean adolescents, dental anxiety is related to oral health behavior, the type of conditions they present with, the treatment received, and dental caries experience. Therefore, systematic programs that could relieve adolescents of dental anxiety should be developed [9]. To date, little is known about dental fear in Koreans. Measures of dental fear appropriate for the Korean population would permit better epidemiological research as well as help in the evaluation of dental fear treatments. Self-report measures of dental fear are commonly used to permit quick assessment of the degree of dental fear experienced by patients. Since there can be cultural differences in various anxiety disorders, including dental fear $[10,11]$, it is important to develop measures appropriate for different cultural groups.

The aim of this study to translate the Dental Fear Survey into Korean for use with children and adolescents.

\section{MATERIALS AND METHODS}

\section{Participants}

The subjects were middle school students in a health promoting school in Gunpo, Gyeonggi Province. A total of 813 students were enrolled in the first survey. Of these, 103 (12.55\%) completed the second survey too.

\section{Methods}

\subsection{Translation of the Dental Fear Survey}

Kleinknecht's 20-item Dental Fear Survey [12] was translated from English into Korean, in accordance with the principles proposed by Gulliemin [13]. The final version was created based on discussions among a dentist, a pediatrician, and an Oriental medicine doctor, all of whom had experience in conducting research with children and adolescents. The English and Korean versions of the DFS are included in the appendix.

\subsection{Characteristics of the Dental Fear Survey}

The DFS consists of a total of 20 items covering "visit avoidance" (2 items), "triggers of physiological responses” (5 items), "dental irritation during dental treatment" (11 items), and "collective horror" (1 item). Items are self-rated and responses are made on a scale from 1 (not at all) to 5 (very much). Each question is assumed to have equal weight, and total scores are obtaining by summing the scores to each question. Participants of this cross-sectional study completed the questionnaires in writing at the study site on May 15, 2012. To assess test-retest reliability, a follow-up survey was conducted four weeks later, on June 18, 2012.

\section{Statistical analysis}

\subsection{Data conversion}

Questionnaire responses were entered into an Excel database and checked for accuracy. No other changes were made to the original data. Only completed questionnaires were analyzed. Analyses were performed with SPSS Version 19.0 (SPSS, Inc., Chicago, IL). A visual inspection showed that general DFS scores were not normally distributed. Relationships between variables were therefore analyzed using the Mann-Whitney test and Kruskal-Wallis test. 


\subsection{Evaluation of reliability}

Reliability and validity testing is a common and necessary procedure in the development of research tools. In the present study, test-retest reliability was determined by calculating Spearman's rank-order correlation coefficient and Cohen's kappa for the scores of the first and second survey. According to Spearman, a correlation coefficient of 0.5 and over can be considered strong. Cronbach's alpha was used to determine internal consistency reliability.

\subsection{Evaluation of validity}

Generally, to determine validity, researchers test content validity, criterion validity and construct validity. In the present study, criterion validity was assessed by calculating the correlation between participants' selfreported scores and observers' ratings, using Spearman's rank-order correlation analysis because the data had a skewed distribution (most participants had low fear levels). Differences in responses to the question "were you ever frightened when you visited a dentist?" were analyzed usinga chi-square test.

\section{RESULTS}

\section{K-DFSscore distribution according to general cha- racteristics}

K-DFS scores did not significantly differ by gender and grade $(\mathrm{P}>0.05)$. Table 1 presents the summary statistics

Table 1. Distribution of scores on the Korean version of the Dental Fear Survey according general characteristics $(n=102)$

\begin{tabular}{llccc}
\hline Variable & Category & Number & Dental Fear Survey average rank & $P^{*}$ \\
Total & & & & \\
Sex & Male & 62 & 49.40 & 0.297 \\
& Female & 40 & 54.75 & 0.814 \\
Grade & $1^{\text {st }}$ & 18 & 49.25 & \\
& $2^{\text {nd }}$ & 10 & 55.65 & 51.49 \\
\hline
\end{tabular}

"P values were calculated using the Mann-Whitney test and Kruskal-Wallis test.

Table 2. Internal consistency reliability

\begin{tabular}{|c|c|c|}
\hline Dental Fear Survey Questions & $\begin{array}{l}\text { Amended Item-Total } \\
\text { Correlation Coefficient }\end{array}$ & $\begin{array}{l}\text { Cronbach's Alpha After } \\
\text { Item is Eliminated }\end{array}$ \\
\hline 1 Has fear of dental work ever caused you to put off making an appointment? & 0.936 & 0.990 \\
\hline 2 Has fear of dental work ever caused you to cancel or not appear for an appointment? & 0.910 & 0.991 \\
\hline 3 When having dental work done: My muscles become tense ... & 0.934 & 0.990 \\
\hline 4 When having dental work done: My breathing rate increases ... & 0.921 & 0.991 \\
\hline 5 When having dental work done:I perspire & 0.890 & 0.991 \\
\hline 6 When having dental work done: I feel nauseated and sick to my stomach ... & 0.870 & 0.992 \\
\hline 7 When having dental work done: My heart beats faster ... & 0.944 & 0.991 \\
\hline 8 Making an appointment for dentistry ... & 0.941 & 0.990 \\
\hline 9 Approaching the dentist's office... & 0.957 & 0.990 \\
\hline 10 Sitting in the waiting room ... & 0.945 & 0.990 \\
\hline 11 Being seated in the dental chair ... & 0.928 & 0.991 \\
\hline 12 The smell of the dentist' office $\cdots$ & 0.922 & 0.991 \\
\hline 13 Seeing the dentist walk in ... & 0.883 & 0.991 \\
\hline 14 Seeing the anesthetic needle ... & 0.889 & 0.991 \\
\hline 15 Feeling the needle injected ... & 0.912 & 0.991 \\
\hline 16 Seeing the drill ... & 0.960 & 0.990 \\
\hline 17 Hearing the drill ... & 0.967 & 0.990 \\
\hline 18 Feeling the vibrations of the drill ... & 0.948 & 0.990 \\
\hline 19 Having your teeth cleaned ... & 0.926 & 0.991 \\
\hline 20 All things considered, how fearful are you of having dental work done? & 0.977 & 0.990 \\
\hline
\end{tabular}

Alpha $=0.991$ Standardized item alpha $=0.992$ 
for the K-DFS in each subgroup.

\section{Reliability testing}

Cronbach's alpha, a measure of internal consistency reliability, was very high for the total K-DFS, at 0.992 (Table 2). Item-total correlations ranged between 0.990 and 0.992 and after adjustment, ranged between 0.883 and 0.977 . The following had relatively low item-total correlations: "When having dental work done: I perspire," "When having dental work done: I feel nauseated and sick to my stomach...," "Seeing the dentist walk in ...," and "Seeing the anesthetic needle ..." If an item was eliminated, the standardized Cronbach's alpha barely changed. In the test-retest reliability analysis, items with Cohen's kappa values below 0.4 or Spearman's correlation coefficients below 0.5 were eliminated. All results are shown in Table 3.

\section{Criterion validity test}

The inspection result, Spearman correlation is -0.934 -0.960 to see a very high correlation. And about "Were you ever frightened when you visited a dentist?”,we

Table 3. Test-retest reliability analysis (Cohen's kappa and Spearman's rank-order correlation coefficient)

\begin{tabular}{|c|c|c|}
\hline Dental Fear Survey Questions & Карра & $\begin{array}{l}\text { Spearman' Rank-Order } \\
\text { Correlation Coefficient }\end{array}$ \\
\hline 1 Has fear of dental work ever caused you to put off making an appointment? & 0.203 & 0.440 \\
\hline 2 Has fear of dental work ever caused you to cancel or not appear for an appointment? & 0.139 & 0.372 \\
\hline 3 When having dental work done: My muscles become tense ... & 0.107 & 0.459 \\
\hline 4 When having dental work done: My breathing rate increases ... & 0.094 & 0.489 \\
\hline 5 When having dental work done: I perspire & 0.071 & 0.488 \\
\hline 6 When having dental work done: I feel nauseated and sick to my stomach ... & 0.334 & 0.092 \\
\hline 7 When having dental work done: My heart beats faster ... & 0.042 & 0.455 \\
\hline 8 Making an appointment for dentistry ... & 0.147 & 0.445 \\
\hline 9 Approaching the dentist's office ... & 0.129 & 0.464 \\
\hline 10 Sitting in the waiting room ... & 0.100 & 0.422 \\
\hline 11 Being seated in the dental chair $\ldots$ & 0.208 & 0.460 \\
\hline 12 The smell of the dentist' office $\cdots$ & 0.097 & 0.481 \\
\hline 13 Seeing the dentist walk in ... & 0.107 & 0.396 \\
\hline 14 Seeing the anesthetic needle ... & 0.119 & 0.369 \\
\hline 15 Feeling the needle injected ... & 0.088 & 0.371 \\
\hline 16 Seeing the drill ... & 0.119 & 0.379 \\
\hline 17 Hearing the drill ... & 0.105 & 0.387 \\
\hline 18 Feeling the vibrations of the drill ... & 0.143 & 0.427 \\
\hline 19 Having your teeth cleaned ... & 0.139 & 0.394 \\
\hline 20 All things considered, how fearful are you of having dental work done? & 0.163 & 0.454 \\
\hline
\end{tabular}

"Kappa < 0.40: normal, 0.41-0.60: moderate, 0.61-0.80 good, > 0.81: very good

"Intra-class correlation coefficient ( ICC ) $=0.991$

${ }^{* *} \mathrm{P}>0.05$

Table 4. Criterion validity test

\begin{tabular}{lcc}
\hline \multicolumn{1}{c}{ Dental Fear Survey Questions } & $\begin{array}{c}\text { Chi-Squared } \\
\text { Test }\end{array}$ & $\begin{array}{c}\text { Spearman' Rank-Order } \\
\text { Correlation Coefficient }\end{array}$ \\
\hline 1 Has fear of dental work ever caused you to put off making an appointment? & -0.960 \\
2 Has fear of dental work ever caused you to cancel or not appear for an appointment? & 0.000 & -0.960 \\
3 When having dental work done: My muscles become tense ... & 0.000 & -0.955 \\
4 When having dental work done: My breathing rate increases ... & 0.000 & -0.934 \\
5 When having dental work done: I perspire & 0.000 & -0.940 \\
6 When having dental work done: I feel nauseated and sick to my stomach ... & 0.000 & -0.942 \\
7 When having dental work done: My heart beats faster ... & 0.000 & -0.941 \\
8 Making an appointment for dentistry ... & 0.000 & -0.941 \\
9 Approaching the dentist's office ... & 0.000 & -0.942 \\
\hline
\end{tabular}




\begin{tabular}{lcc}
\multicolumn{1}{c}{ Dental Fear Survey Questions } & $\begin{array}{c}\text { Chi-Squared } \\
\text { Test }\end{array}$ & $\begin{array}{c}\text { Spearman' } \\
\text { Correlation Coefficient }\end{array}$ \\
\hline 10 Sitting in the waiting room ... & 0.000 & -0.943 \\
11 Being seated in the dental chair ... & 0.000 & -0.942 \\
12 The smell of the dentist' office ... & 0.000 & -0.941 \\
13 Seeing the dentist walk in ... & 0.000 & -0.942 \\
14 Seeing the anesthetic needle ... & 0.000 & -0.943 \\
15 Feeling the needle injected ... & 0.000 & -0.943 \\
16 Seeing the drill ... & 0.000 & -0.943 \\
17 Hearing the drill ... & 0.000 & -0.942 \\
18 Feeling the vibrations of the drill ... & 0.000 & -0.941 \\
19 Having your teeth cleaned ... & 0.000 & -0.941 \\
20 All things considered, how fearful are you of having dental work done? & 0.000 & -0.942 \\
\hline
\end{tabular}

${ }^{*} \mathrm{P}>0.05,{ }^{* *} \mathrm{P}>0.05$

answer a result of a response to category 20 is the difference between a survey in both Statistically significant. It showed that the $\mathrm{P}<0.05$ (Table 4).

\section{DISCUSSION}

Generally measure of dental fear according adult population, there were many methods, Corah Dental Anxiety Scale (DAS) [14], Modified Dental Anxiety Scale (MDAS) [15], Weiner's Fear Questionnaire (FQ), Dental Anxiety Inventory (DAI) [16] and short dental anxiety inventory (S-DAI) [17], Dental Fear Survey (DFS) [18], State-Trait Anxiety Inventory (STAI) [19], Adolescents' Fear of Dental Treatment Cognitive Inventory (AFDTCI) [20]. Frequently the two most used measures of overall dental fear in adults are Corah's Dental Anxiety Scale (DAS) [14] and Kleinknecht's Dental Fear Survey (DFS) [18].

The original DFS contained 27 items [18], which the authors later reduced to 20 [12]. Both were originally developed in English. The original DAS is a 4-item questionnaire, asking respondents to rate their anxiety as they imagine approaching four dental stimuli, such as contemplating going to the dentist tomorrow. Each item is answered on a 5-point scale, so that scores may range from 4 (no fear) to 20 (highest level of fear). The Modified Dental Anxiety Scale (MDAS) [15] was developed to improve the psychometrics and content validity of the original DAS. It consists of five items, and total scores may range from 5 (no fear) to 25 (highest level of fear). The MDAS has been found to be reliable and valid in several samples from England, Scotland, Wales, Ireland, Finland Dubai, Brazil, and Turkey [15,21-24]. The DFS assess a broader array of dental stimuli than the MDAS, such as seeing the drill, smelling the dental office, and the like. In addition, the respondent is asked to rate specific physiological responses to dental stimuli, such as muscle tension and increased breathing rates. Two items assess avoidance of dental appointments due to fear, and one item asks for an overall rating of fear of dental work. Each item is rated on a 5-point scale. Possible scores range from 20 (no fear) to 100 (highest level of fear). The DFS has been found to be reliable and valid in samples of college students and dental patients [16]. The measure has been translated into a number of languages, including Danish, Swedish, Norwegian, Hungarian, Brazilian, Turkish, Chinese and Malay [25-32]. To our knowledge, no Korean version of the DFS has been developed. Therefore, we elected to perform our own translation of this measure, and developed a Korean version of the DFS for use with children and adolescents, with good construct validity. However, the K-DFS had unexpectedly low test-retest reliability $(0.4 ; 95 \% \mathrm{CI}=0.34-0.85)$, measured by intraclass correlation coefficients in a sample of middle 
school students over a four-week interval.

In conclusion, this study is the first to develop a Korean version of the DFS. We created and assessed a new translation of the 20-item DFS for Korean adolescents. The internal consistency reliability of the K-DFS was very good, with Cronbach's alpha coefficients ranging from 0.80 to 0.96 . It also had good test-retest validity but its test-retest reliability was lower than expected. Therefore, we need to further examine the test-retest reliability of the K-DFS and replicate the current study in different samples covering various age groups.

Funding: The authors deny any conflicts of interest. Declaration of interest: The authors have no conflicts of interest to disclose.

\section{REFERENCES}

1. Ministry of Health and Welfare. Korean Oral Health National Survey 2000. Seoul.

2. Ministry of Health and Welfare. Korean Oral Health National Survey 2006. Seoul.

3. Ministry of Health and Welfare. Korean Oral Health National Survey 2012. Seoul.

4. Glick M, Monteiro O, Seeberger GK, Xu T, Pucca G, Williams DM, et al. FDI Vision 2020: shaping the future of oral health. Int Dent J 2012; 62: 278-91.

5. Armfield JM, Stewart JF, Spencer AJ. The vicious cycle of dental fear: exploring the interplay between oral health, service utilization and dental fear. BMC Oral Health 2007; 14; 7: 1-15.

6. Schuller AA, Willumsen T, Holst D. Are there differences in oral health and oral health behavior between individuals with high and low dental fear? Community Dent Oral Epidemiol 2003; 31: 116-21.

7. Pohjola V, Lahti S, Vehkalahti MM, Tolvanen M, Hausen H. Age-specific associations between dental fear and dental condition among adults in Finland. Acta Odontol Scand 2008; 66: 278-85.
8. Locker D, Liddell A. Clinical correlates of dental anxiety among older adults. Community Dent Oral Epidemiol 1992; 20: 372-75

9. Park SH, Lee NG, Ju HJ, Choi BY, Oh HW, Lee HS. Relationship of dental anxiety with oral health behavior and dental caries experience in adolescents. J Korean Acad Oral Health 2015; 39: 17-24

10. Good BJ, Kleinman AM. Culture and anxiety: cross-cultural evidence for the patterning of anxiety disorders. In: Anxiety and the Anxiety Disorders. Edited by Tuma AH, Maser J, Hillsdale NJ, England, Lawrence Earlbaum. 1985, pp 297-323.

11. Humphris GM, Freeman R, Campbell J, Tuutti H, D'Souza D. Further evidence for the reliability and validity of the Modified Dental Anxiety Scale. Int Dent J 2000; 50: 367-70.

12. Kleinknecht RA, Thorndike RM, McGlynn FD, Harkavy J. Factor analysis of the dental fear survey with cross-validation. J Am Dent Assoc 1984; 108: 59-61.

13. Guillemin F, Bombardier C, Beaton D. Cross-cultural adaptation of health-related quality of life measures: literature review and proposed guidelines. J Clin Epidemiol 1993; 46: 1417-32.

14. Corah NL. Development of a dental anxiety scale. J Dent Res 1969; 48: 596.

15. Humphris GM, Morrison T, Lindsay SJE. The Modified Dental Anxiety Scale: validation and United Kingdom norms. Community Dent Health 1995; 12: 143-50.

16. Schuurs AH, Hoogstraten J. Appraisal of dental anxiety and fear questionnaires: a review. Community Dent Oral Epidemiol. 1993; 21: 329-39.

17. Aartman IH. Reliability and validity of the short version of the Dental Anxiety Inventory. Community Dent Oral Epidemiol. 1998; 26: 350-4.

18. Kleinknecht RA, Klepac RK, Alexander LD: Origins and characteristics of fear of dentistry. J Am Dent Assoc 1973; 86: $842-8$.

19. Weisenberg M, Kreindler ML, Schachat R. Relationship of the dental anxiety scale to the state-trait anxiety inventory. J Dent Res. 1974; 53: 946.

20. Gauthier JG, Ricard S, Morin BA, Dufour L, Brodeur JM. La peur destraitements chez les jeunes adolescents: 
developpement et evaluation d'une mesure cognitive. J Can Dent Assoc 1991; 57: 658-62.

21. Alvesalo I, Murtomaa H, Milgrom P, Honkanen A, Karjalainen M, Tay K-M. The dental fear survey schedule: a study with Finnish children. Int J Paediatr Dent Dec 1993; 3(4): 193-8.

22. Kanegane K, Penha SS, Borsatti MA, Rocha RG. Dental anxiety in an emergency dental service. Rev Saude Publica 2003; 37: 786-92.

23. Tunc EP, Firat D, Onur OD, Sar V. Reliability and validity of the Modified Dental Anxiety Scale (MDAS) in a Turkish population. Community Dent Oral Epidemiol 2005; 33: 357-62.

24. İlguy D, İlguy M, Dincer S, Bayirli G. Reliability and validity of the Modified Dental Anxiety Scale in Turkish patients. J Int Med Res 2005; 33: 252-9.

25. Moore R, Birn H, Scheutz F et al. Prevalence and characteristics of dental anxiety in Danish adults. Community Dent Oral Epidemiol 1993; 21: 292-6.

26. Moore R, Berggren U, Carlsson SG. Reliability and clinical usefulness of psychometric measures in a self-referred population of odontophobics. Community Dent Oral Epidemiol 1991; 19: 347-51.

27. Johansson P, Berggren U. Assessment of dental fear: a comparison of two psychometric instruments. Acta Odontol Scand 1992; 50: 43-9.

28. Kvale G, Berg E, Nilsen CM, Raadal M, Nielsen GH, Johnsen TB, et al. Validation of the Dental Fear Scale and the Dental Belief Scale in a Norwegian sample. Community Dent Oral Epidemiol 1997; 25: 160-4.

29. Fabian TK, Handa T, Szabo M, Kelemen P, Kaan B, Fabian G. A “Dental Fear Survey" (a "Fogaszati felelem kerdoiv") magyar forditasa, hazai populacion vegzett meresek eredmenyei. Fogorv Sz 1999; 92: 307-15.

30. Cesar J, de Moraes ABA, Milgrom P, Kleinknecht RA. Cross validation of a Brazilian version of the Dental Fear Survey. Community Dent Oral Epidemiol 1993; 21: 148-50.

31. Firat D, Tunc EP, Sar V. Dental anxiety among adults in Turkey. J Contemp Dent Pract 2006, 7: 75-82.

32. Milgrom P, Kleinknecht RA, Elliott J, Hsing LH, Choo-Soo T. A crosscultural validation of the Dental Fear Survey in South East Asia. Behav Res Ther 1990; 28: 227-33. 
Appendix.

\section{Korean DFS items}

1. 치과에 가는 것이 두려워서 치료날짜를 뒤로 미룬 적이 있다.

2. 치과에 가는 것이 두려워서 치료 약속을 취소한 적이 있다.

3. 치과에 들어서면 근육이 긴장되는 것 같다.

4. 치과에 들어서면 호흡이 빨라지는 것 같다.

5. 치과에 들어서면 진땀이 난 적이 있다.

6. 치과에 들어서면 구역질을 한 적이 있다.

7. 치과에 들어서면 심장이 쿵쾅거린다.

8. 치과 치료 약속을 정할 때면 두려움을 느낀다.

9. 치과에 도착 했을 때 두려움을 느낀다.

10. 대기실에서 치료를 기다릴 때 두려움을 느낀다.

11. 치료 의자에 앉아 치료를 기다릴 때 두려움을 느낀다.

12. 치과의 특유한 냄새를 맡았을 때 두려움을 느낀다.

13. 치과의사를 쳐다볼 때 두려움을 느낀다.

14. 마취용 주사바늘을 볼 때 두려움을 느낀다.

15. 주사바늘이 살을 찌를 때 두려움을 느낀다.

16. 치아 삭제용 기구(드릴)를 보고 두려움을 느낀다.

17. 치아 삭제용 기구가 돌아가는 소리를 들을 때 두려움을 느낀다.

18. 치아가 삭제되고 있는 느낌을 받을 때 두려움을 느낀다.

19. 치석을 제거(스켈링)할 때 두려움을 느낀다.

20. 위 사항들을 고려할 때 치과치료에 대한 전체적인 느낌은 나쁘다.

\section{English DFS items}

1. Has fear of dental work ever caused you to put off making an appointment?

2. Has fear of dental work ever caused you to cancel or not appear for an appointment?

When having dental work done:

3. My muscles become tense ...

4. My breathing rate increases ...

5. I perspire

6. I feel nauseated and sick to my stomach ...

7. My heart beats faster ...

8. Making an appointment for dentistry ...

9. Approaching the dentist's office ...

10. Sitting in the waiting room ...

11. Being seated in the dental chair

12. The smell of the dentist' office ...

13. Seeing the dentist walk in ...

14. Seeing the anesthetic needle ...

15. Feeling the needle injected ...

16. Seeing the drill ...

17. Hearing the drill ...

18. Feeling the vibrations of the drill ...

19. Having your teeth cleaned...

20. All things considered, how fearful are you of having dental work done? 